\title{
REVISI UNDANG-UNDANG PERLINDUNGAN DISABILITAS: AKSESBILITAS PERLINDUNGAN HUKUM TERHADAP KEKERASAN SEKSUAL
}

\author{
Dylan Aldianza Ramadhan*, Alfia Septiani Solekhah, Fitrah Marinda \\ Universitas Tarumanagara*, Universitas Islam Negeri Walisongo, Universitas \\ Hasanuddin \\ Correspendent Email: Dylan.205180227@stu.untar.ac.id
}

Naskah diterima: 29/10/2021, Revisi: 15/11/2021, Disetujui: 31/12/2021

\begin{abstract}
Abstrak
Belakangan di Indonesia ramai dengan maraknya kasus kekerasan seksual, seolah berita hukuman berat pada para pelaku tidak menjadi ketakutan bagi para pelaku yang baru. Belum lama ini kita dikejutkan dengan berita wanita penyandang disabilitas yang diperkosa 3 orang pria di condet. Hal itu mengetuk mata kita bahwa persoalan nafsu tidak memandang objek, ketika seseorang digelapkan pada persoalan nafsu maka apa yang di depan mata akan menjadi sasaran pelampiasan libidonya. Dimana kita ketahui adanya budaya patriarki di Indonesia yang tidak pro pada wanita, ditambah ketika wanita tersebut merupakan orang penyandang disabilitas, maka sulit membayangkan betapa beratnya beban yang perlu ditanggung para wanita disabilitas korban kekerasan ini. Maka darinya latar belakang keprihatinan yang mengajak penulis untuk meneliti terakhir ini. Metode penelitian yang digunakan yaitu yuridis normatif, dengan beberapa pendekatan yaitu: pendekatan perundang-undangan, pendekatan konseptual, pendekatan historis, pendekatan kasus, dan pendekatan perbandingan. Kemudian, tidak membatasi pada kajian pustaka saja penulis berusaha menyelam pada realitas di lapangan dengan penelitian empiris untuk mendapatkan gambaran secara komprehensif. Berdasarkan analisis penulis didapati urgensi merevisi UU Perlindungan Disabilitas Perlindungan, dimana Ketika UU a quo ini direvisi maka kelak akan bisa menjadi payung hukum yang berpihak pada para penyandang disabilitas dan lebih komprehensif. Kemudian untuk mengoptimalisasikannya kelak maka perlu segera mengesahkan RUU PKS juga. Dari kolaborasi keduanya maka akan menciptakan ruang keberpihakan pada Wanita, disabilitas, anak, dan korban kekerasan seksual. Kesimpulan, Merevisi UU Perlindungan Disabilitas bisa menjadi aksesibilitas untuk pencegahan kekerasan seksual. Saran penulis, sebaiknya DPR melakukan revisi UU tentang perlindungan pada Disabilitas sesegera mungkin.
\end{abstract}

How to cite:

Ramadhan, D., Solekhah, A., \& Marinda, F. (2021). Revisi Undang-Undang Perlindungan Disabilitas: Aksesibilitas Perlindungan Hukum Terhadap Kekerasan Seksual. Ikatan Penulis Mahasiswa Hukum Indonesia Law Journal, 1(2)

Diterbitkan oleh:

Ikatan Penulis Mahasiswa Hukum Indonesia

IPMHI Law Journal

${ }^{\circledR} 2021$ Author 
Kata Kunci : Disabilitas, Aksesibilitas, Kekerasan seksual, Revisi UU, Difabel.

\section{PENDAHULUAN}

\section{Latar Belakang}

Catatan tahunan (CATAHU) komnas perempuan pada tahun 2021 melansir terdapat 299.911 kasus kekerasan terhadap perempuan sepanjang tahun 2020, data tersebut dihimpun dari tiga sumber yakni Pengadilan Negeri/Pengadilan Agama, Lembaga Layanan Mitra Komnas Perempuan, dan Unit Pelayanan dan Rujukan (UPR) Komnas Perempuan. Pada kekerasan ranah pribadi jumlah kasus kekerasan seksual mendominasi 30\% (1.983 kasus) yang menduduki peringkat kedua setelah kekerasan fisik. Komnas Perempuan juga mencatat adanya 77 kasus kekerasan terhadap perempuan penyandang disabilitas, dimana penyandang disabilitas intelektual mendominasi $45 \%$ sebagai kelompok yang paling rentan mengalami kekerasan. ${ }^{1}$ Adapun berikut grafik detail data mulai dari dari kekerasan seksual pada disabilitas dan jumlah perempuan disabilitas berdasarkan lembaga.

Gambar 1. Data kasus perempuan dengan disabilitas berdasarkan lembaga CATAHU 2021

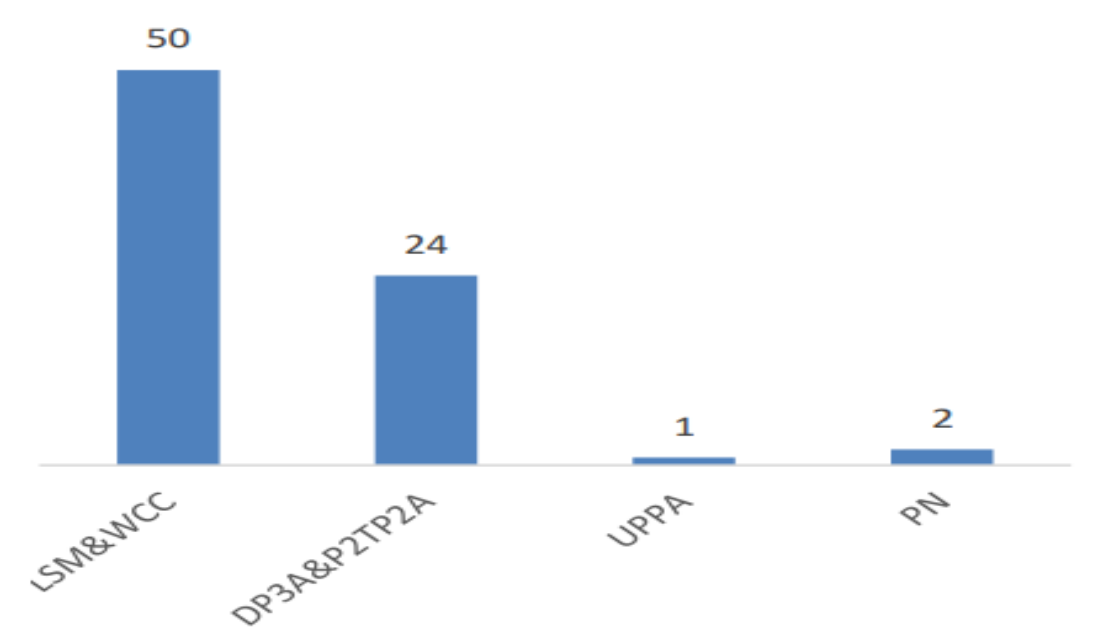

Gambar 2. Jumlah Disabilitas Perempuan Korban Kekerasan Tahun 2020 CATAHU $2021^{3}$

\footnotetext{
${ }^{1}$ Komnas Perempuan, Catahu (2021). Catatan Tahunan Kekerasan Terhadap Perempuan Tahun 2020 KOMNAS PEREMPUAN, Jakarta: Komnas Perempuan, 2021, hlm. 44.

2 Ibid.,hlm 43.

3 Ibid., hlm. 44.
} 


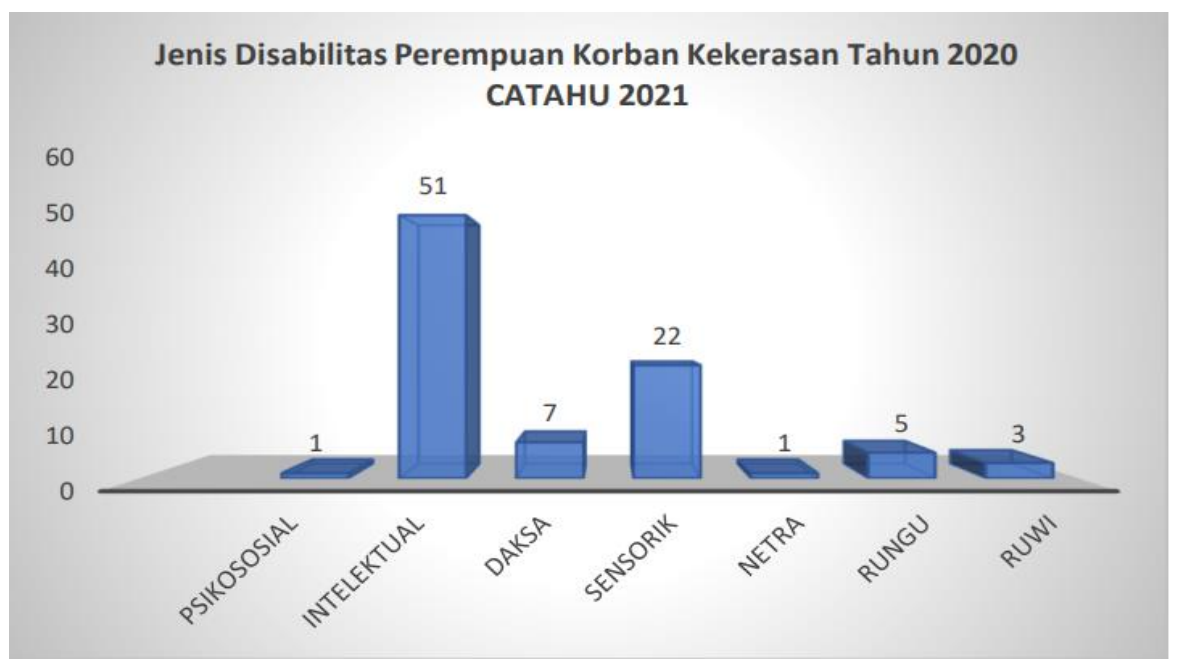

Gambar 3. Bentuk dan Ranah Ktp Disabilitas Tahun 2020

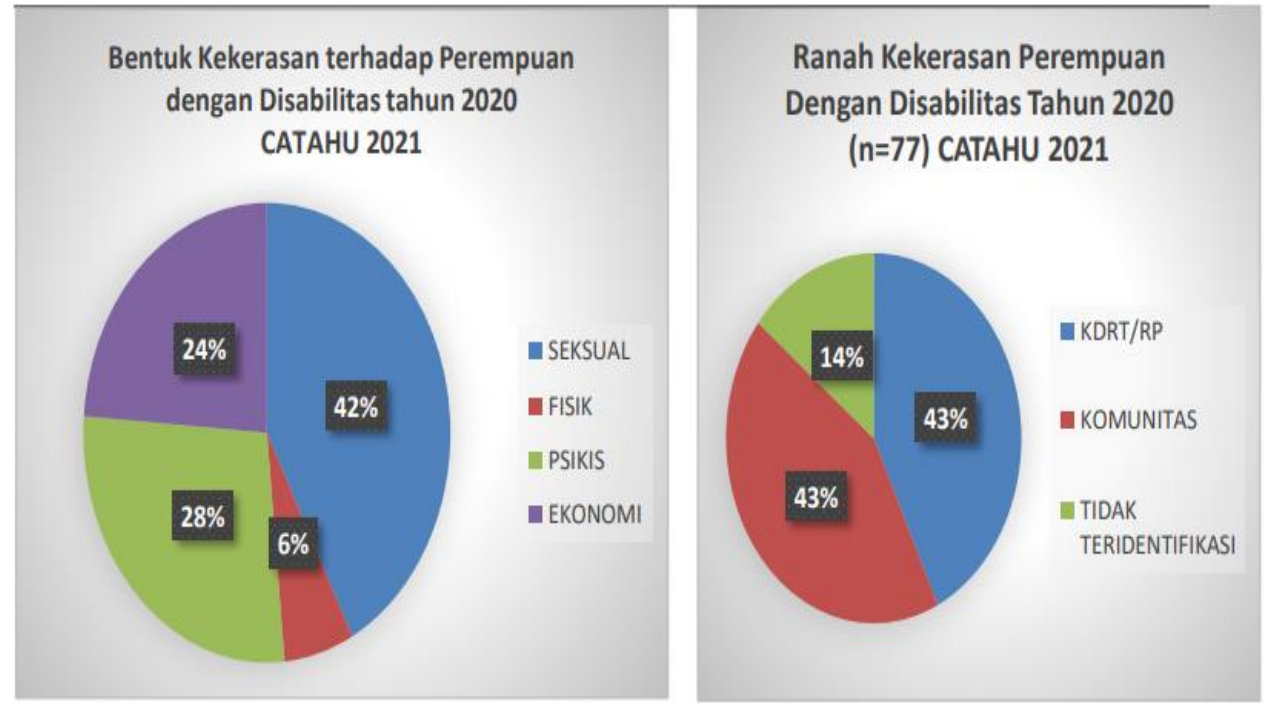

Dari temuan fakta di atas mengenai rentetan data Ktp Disabilitas menjadikan tanda tanya besar mengenai mengapa angka kekerasan pada orang-orang yang sejatinya dilindungi oleh negara masih tergolong banyak. Perlindungan pada disabilitas sendiri sudah diatur dalam UU No 8 tahun 2016 tentang penyandang Disabilitas. Peristilahan disabilitas sendiri sejatinya sudah dijauhi karena dianggap tidak manusiawi dan diskriminatif, dan digantikan dengan istilah difabel. Difabel dilindungi dikarenakan mereka dianggap masuk pada kelompok tertindas (oppressed group) lainnya seperti perempuan, etnis minoritas, lesbian, dan gay karena mereka juga mengalami diskriminasi atau penindasan sosial. .

Menurut Laudon, e-commerce adalah suatu internet, web, dan aplikasi yang berfungsi untuk melakukan transaksi bisnis secara digital antara perusahaan dan individu. Sedangkan menurut Turban, e-commerce adalah suatu internet yang berfungsi untuk membeli, menjual, mengangkut, atau memperdagangkan data, barang atau jasa. Kemudian Savrul menjelaskan e-commerce dalam dua lingkup yaitu definisi dalam lingkup luas dan lingkup sempit. Menurut definisi luas, $e$ commerce ialah jual beli barang antara bisnis, rumah tangga, individu, pemerintah dan organisasi publik dan swasta lainnya yang dihubungkan melalui

4 Ibid. 
jaringan komputer. Definisi sempit pada dasarnya hampir sama dengan definisi luas, kecuali instrumen perdagangan terbatas dengan internet. ${ }^{5}$

Difabel di mata masyarakat saat ini masih dipandang sebelah mata sebagai pihak yang perlu dikasihani. ${ }^{6}$ Perlakuan khusus tersebut dipandang sebagai usaha maksimalisasi penghormatan, pemajuan, perlindungan dan pemenuhan hak asasi manusia secara universal. ${ }^{7}$ Kaum difabel juga memiliki hak yang harus dilindungi sebagaimana manusia normal pada umumnya. Namun karena keterbatasan yang mereka miliki maka ada pula hak khusus bagi mereka yang harus kita hargai dan lindungi. ${ }^{8}$

Disamping dengan Undang-Undang tentang penyandang disabilitas, pemerintah juga telah melakukan upaya melindungi hak penyandang disabilitas melalui berbagai peraturan Perundang Undangan, antara lain: peraturan yang mengatur masalah ketenagakerjaan, kesehatan, pendidikan, kesejahteraan sosial, lalu lintas dan angkutan jalan, perkeretaapian, pelayaran, dan penerbangan. Peraturan Perundang-undangan tersebut memberikan jaminan kepada Penyandang disabilitas agar mendapatkan kemudahan (aksesibilitas). ${ }^{9}$ Indonesia telah memiliki regulasi nasional, diantaranya Peraturan Menteri Pekerjaan Umum Nomor 3 Tahun 2006 tentang Pedoman Teknis Fasilitas dan Aksesibilitas pada Bagunan Gedung dan Lingkungan. ${ }^{10}$ Kemudian,Undang-Undang Dasar 1945 menjamin kesetaraan hak dan kesempatan setiap warga negara, termasuk warga negara difabel (khususnya lihat Pasal $28 \mathrm{H}$ ayat 2, dan Pasal 28 I ayat 2). UU No. 69 tahun 1999 tentang HAM (khususnya lihat Pasal 3, 5, dan 41), UU No. 13 tahun 2003 tentang Ketenagakerjaan (khususnya lihat Pasal 28), UU No. 23 tahun 2002 tentang Perlindungan Anak (khususnya lihat Pasal 8, 9, 11, 12, 13), UU No. 20 tahun 2003 tentang Sistem Pendidikan Nasional (khususnya lihat Pasal 5 dan 23). ${ }^{11}$

Lahirnya UU NO.8/2016 merupakan angin segar bagi penyandang disabilitas yang mengubah paradigma terhadap seluruh kaum penyandang disabilitas yang awalnya masuk dalam objek kebijakan yang hanya fokus terhadap kesejahteraan, kesehatan dan program santunan namun berdasarkan asas persamaan hak maka dilaksanakanlah upaya penghormatan, perlindungan dan pemenuhan hak serta pemberdayaan penyandang disabilitas. ${ }^{12}$ UU No 8 Tahun 2016 lahir sebagai bentuk revisi pada UU sebelumnya yaitu UU 4 Tahun 1997 tentang Penyandang Cacat yang dianggap belum mengakomodir hak para disabilitas kala ini.

5 Decky Hendarsyah, "E-Commerce di Era Industri 4.0 dan Society 5.0”, 2019, Vol 8, No 2, QTISHADUNA: Jurnal Ilmiah Ekonomi Kita, Sekolah Tinggi Ilmu Ekonomi (STIE) Syariah Bengkalis, hlm. 172-173.

${ }^{6}$ Rima Setyaningsih (2016). Pengembangan Kemandirian Bagi kaum Difabel, Jurnal Sosiologi Dilema, Vol. 31, No.1, hlm. 43.

${ }^{7}$ Budiyono, Muhtadi \& Ade Arif Firmansyah (2015). Dekonstruksi Urusan Pemerintah Konkuren Dalam Undang-Undang Pemerintahan Daerah”, Kanun Jurnal Ilmu Hukum, No. 67, hlm. 416.

8 Muhammad Miftahul Umam \& Ridwan Arifin (2019). Aksesibilitas Kaum Difabel Dalam Perlindungan Hukumnya Dalam Perspektif Hak Asasai Manusia”, Pena Jurnal, Vol. 18, No.1, hlm. 52.

${ }^{9}$ H. Muladi (2005). Hak Asasi Manusia Hakekat, Konsep \& Implikasi Dalam Perspektif Hukum dan Masyarakat, Bandung: Refika Aditama, hlm. 225.

${ }^{10}$ Slamet Tohari (2014). Pandangan Disabilitas dan Aksesibilitas Fasilitas Publik bagi Penyandang Disabilitas di Kota Malang, Indonesia Journal Of Disability Studies, Vol. 1, No. 1, hlm.29.

11 Sunarman Sukamto, Best Practice Advokasi Kebijakan Daerah Perperspektif Difabel: Pengalaman PPRBM Solo, Solo: PPRBM Solo, hlm. 2.

${ }^{12}$ Frichy Ndaumanu (2020). Hak Penyandang Disabilitas: Antara Tanggung Jawab dan Pelaksanaan Oleh Pemerintah Daerah, Jurnal HAM, Vol. 11, No. 1, hlm. 132-133. 
Tingginya kasus kekerasan seksual pada penyandang disabilitas di Indonesia disebabkan oleh berbagai macam faktor, diantaranya karena masih adanya budaya patriarki, yang mana dalam budaya tersebut terdapat rape culture yang masih sangat kuat, sehingga masyarakat akan cenderung lebih menyalahkan korban daripada pelaku, korban penyandang disabilitas seringkali tidak mendapatkan keadilan karena sulit memberikan bukti pada proses peradilan sehingga pelaku mudah lolos dari jeratan hukum. Karakter yang dimiliki penyandang disabilitas juga seringkali dimanfaatkan oleh para pelaku untuk menjadikan korban sebagai sasaran empuk karena dinilai sebagai target yang mudah (easy target). Menurut Komnas Perempuan dalam (Idris 2020) selain karakter alami disabilitas, kerentanan disabilitas menjadi korban kekerasan seksual juga disebabkan oleh nilai sosial yang biasa diajarkan pada penyandang disabilitas untuk selalu bersikap patuh. ${ }^{13}$

Adanya perubahan UU No.4 tahun 1997 tentang penyandang cacat menjadi UU No. 8 tahun 2016 tentang penyandang disabilitas ini mengacu pada Convention on The Rights of Persons with Disabilities yang merupakan bentuk wujud kepedulian pemerintah terhadap pemenuhan hak-hak penyandang disabilitas. Namun pada kenyataannya perubahan UU tersebut belum dapat memenuhi kebutuhan korban kekerasan seksual yang dialami oleh para penyandang disabilitas dalam hal perlindungan hukum secara komprehensif, karena apabila kita merujuk pada Pasal 5 UU No.31 Tahun 2014 tentang perubahan UU No.13 Tahun 2006 tentang Perlindungan Saksi dan Korban, yang mana menjelaskan tentang perlindungan dan hak-hak korban yang seharusnya memperoleh perlindungan atas keamanan pribadi, bebas dari ancaman, memperoleh biaya hidup sementara, dan mendapatkan pendampingan baik dalam segi mental maupun fisik.

Berlandaskan pada penjabaran temuan mengenai kesenjangan di atas menjadikan landasan penulis untuk mengkaji lebih komprehensif mengenai korelasi dan efektifitas UU No 8 Tahun 2016 khususnya pada litigasi dan pemenuhan hak-hak para disabilitas yang menjadi korban kekerasan seksual. Penelitian ini bertujuan mengkonkritkan dan memperkaya khasana ilmu pengetahuan khususnya pada topik yang berkaitan dengan disabilitas. Penelitian ini akan bermuara pada rekomendasi apakan perlu tidaknya melakukan revisi pada UU Perlindungan Disabilitas. Maka penulis tertarik untuk mengangkat permasalahan tersebut dengan judul "Revisi Undang-Undang Disabilitas: Aksesibilitas Perlindungan Hukum Terhadap Kekerasan Seksual” .

\section{Rumusan Masalah}

Dari latar belakang diatas maka rumusan masalah yang diangkat pada penulisan karya ilmiah ini antara lain:

1. Bagaimana hukum positif mengatur terkait perlindungan Disabilitas pada kekerasan seksual?

2. Bagaimana Urgensi Revisi Undang-undang tentang Perlindungan Disabilitas?

3. Apakah dengan Revisi UU tentang Perlindungan Disabilitas bisa menjadi akses para penyandang mendapat perlindungan hukum pada kekerasan seksual di Indonesia?

\footnotetext{
${ }^{13}$ M.idris (2020). Upaya Perlindungan Hukum Terhadap Kaum Penyandang Disabilitas Dari Kejahatan Pelecehan Seksual (Studi Kasus Unit Pelaksana Teknis Daerah Perlindungan Perempuan Dan Anak (UPTD PPA) Kota Jambi), Jambi: UIN Sutha Jambi, hlm. 36-37.
} 


\section{METODE}

1. Jenis Penelitian

Istilah "metode" berasal dari Bahasa Yunani, yaitu "methodos" yang berarti cara bertindak menurut sistem aturan tertentu atau prosedur untuk mencapai sesuatu melalui langkah-langkah yang sistematis. ${ }^{14}$ Istilah metodologi penelitian diartikan sebagai ilmu tentang cara melakukan penelitian (hukum) dengan teratur dan sistematis yang berfungsi untuk memberikan pedoman tentang tata cara seorang peneliti mempelajari, menganalisis, memahami dalam penelitian hukum. ${ }^{15}$

Penelitian hukum yang digunakan pada penelitian ini secara spesifik menggunakan penelitian hukum normatif. Menurut Soerjono Soekanto dan Sri Mamudji, definisi dari penelitian hukum normatif merupakan penelitian hukum yang dilakukan dengan cara meneliti bahan pustaka atau data sekunder belaka. ${ }^{16}$ Berdasarkan uraian di atas, maka penelitian ini merupakan penelitian hukum normatif dengan menggunakan pendekatan terhadap peraturan perundang-undangan yang ditinjau dari sudut hierarki perundang-undangan (vertikal) dan hubungan harmoni perundang-undangan (horizontal), pendekatan konseptual, dan pendekatan komparatif atau perbandingan hukum sebagai upaya untuk menguraikan pokok permasalahan yang ditetapkan untuk menghasilkan suatu rekomendasi yang konstruktif bagi perkembangan ilmu hukum dan mewujudkan kesejahteraan masyarakat.

2. Teknik Pengumpulan Data

Data yang diperoleh dalam penelitian ini adalah data dasar yang berupa data sekunder. Menurut Sugiyono, data sekunder adalah data yang diperoleh dengan cara membaca, mempelajari, dan memahami informasi melalui media lain yang bersumber dari literatur, buku-buku, serta dokumen. ${ }^{17}$ Dalam penelitian ini, data sekunder diperoleh secara tidak langsung dari sumber data, yaitu diperoleh melalui data yang sudah ada sebelumnya yang didapatkan dengan membaca, memahami, dan mempelajari berbagai buku hukum, jurnal hukum yang berisi prinsip-prinsip dasar, pandangan para ahli hukum, hasil penelitian hukum, kamus hukum, ensiklopedi hukum, serta sumber informasi lain yang relevan dengan isu hukum yang ditetapkan.

Data sekunder dalam penelitian ini dibedakan menjadi bahan hukum primer, bahan hukum sekunder, ${ }^{18}$ dan bahan non hukum. ${ }^{19}$ Adapun penjabarannya sebagai berikut:

a. Bahan Hukum Primer, terdiri dari:

1) Undang-Undang Dasar Negara Republik Indonesia Tahun 1945;

2) Undang-Undang Nomor 19 Tahun 2011 tentang Ratifikasi

Konvensi Hak-hak Penyandang Disabilitas; dan

3) Undang-Undang Nomor 8 Tahun 2016 tentang Penyandang

\footnotetext{
${ }^{14}$ Husaini Usman dan Purnomo Setiady Akbar (1996). Metodologi Penelitian Sosial, Jakarta: Bumi Aksara, hlm. 42.

${ }^{15}$ H. Ishaq (2017). Metode Penelitian Hukum dan Penulisan Skripsi, Tesis, serta Disertasi, Bandung: Alfabeta, hlm. 26.

${ }^{16}$ Soerjono Soekanto dan Sri Mamudji (2019). Penelitian Hukum Normatif (Suatu Tinjauan Singkat), Cetakan Ke-19, Jakarta: Raja Grafindo, hlm. 23.

${ }^{17}$ Sugiyono (2012). Memahami Penelitian Kualitatif, Bandung: Alfabeta, hlm. 141.

${ }^{18}$ Peter Mahmud Marzuki (2019). Penelitian Hukum, Cetak ke-19, Jakarta: Pranada Media Group, h. 181.

${ }^{19}$ Peter Mahmud Marzuki (2017). Penelitian Hukum Edisi Revisi,Cetak ke-13, Jakarta: Kencana Prenada Media Group, hlm. 60.
} 
Disabilitas.

b. Bahan Hukum Sekunder, terdiri dari:

1) Buku-Buku Hukum;

2) Jurnal-Jurnal Hukum;

3) Hasil Penelitian Hukum;

4) Doktrin para ahli hukum.

c. Bahan Non Hukum, terdiri dari:

1) Kamus Bahasa;

2) Kamus Hukum;

3) Wawancara dan Forum Group Discussion (FGD).

3. Teknik Analisis Data

Bahan hukum primer yang digunakan oleh Penulis adalah bahan-bahan hukum yang bersifat otoritatif dan mempunyai kekuatan mengikat seperti peraturan perundang-undangan dengan isu penulis. ${ }^{20}$ Metode pendekatan dalam karya ilmiah ini menggunakan pendekatan:

a. Pendekatan Perundang-undangan (statute approach) $;{ }^{21}$

b. Pendekatan kasus (Case approach) ${ }^{22}$

c. Pendekatan konseptual (Conceptual approach);

d. Pendekatan historis (Historical approach); ${ }^{23}$

e. Pendekatan perbandingan (Comparative approach).

Analisis yang digunakan dalam penelitian ini adalah metode analisis yang bersifat kualitatif yaitu analisis yang tidak menggunakan angka, melainkan memberikan gambaran dengan kata-kata atas temuan-temuan yang lebih mengutamakan mutu atau kualitas dari data dan bukan kuantitas. ${ }^{24}$ Analisis kualitatif ini menghasilkan data deskriptif analisis, yaitu apa yang dinyatakan oleh responden secara tertulis atau lisan dan juga perilakunya yang nyata, diteliti dan dipelajari sebagai sesuatu yang utuh. ${ }^{25}$

Analisis kualitatif dilakukan dengan menggunakan penafsiranpenafsiran terhadap hukum agar dapat menentukan apakah bahan hukum yang diperoleh terdapat kekosongan norma hukum, antinomi hukum, dan/atau norma hukum yang tidak jelas atau tidak tegas.

\section{HASIL PENELITIAN DAN PEMBAHASAN}

\section{Hukum Positif yang mengatur terkait perlindungan Disabilitas}

Sudah beberapa repetitif penulis menyinggung mengenai aturan hukum yang melindungi difabel di Indonesia, adapun aturan mengatur terkait perlindungan disabilitas antara lain:

a. Undang-Undang Dasar Negara Republik Indonesia 1945.

Pada dasar pijakan sebagai perlindungan hukum pada disabilitas diatur langsung dalam konstitusi negara kita. Konstitusi sebagai dasar perlindungan disabilitas menjadikan dasar filosofis. Pasal-pasal terkait yang sekaran implisit mengandung pemaknaan

\footnotetext{
${ }^{20}$ Ibid., hlm. 205.

${ }^{21}$ Peter Mahmud Marzuki, Op.Cit., hlm.132.

${ }^{22}$ Peter Mahmud Marzuki, Op.Cit., hlm. 177.

${ }^{23}$ Peter Mahmud Marzuki, Op.Cit., hlm. 166.

${ }^{24}$ Meruy Hendrik Mezak (2006). Jenis, Metode, dan Pendekatan dalam Penelitian Hukum, Jurnal Law Review, Vol. 5, No. 3, h. 94.

${ }^{25}$ Soerjono Soekanto (2001). Penelitian Hukum Normatif Suatu Tinjauan Singkat, Jakarta: Raja Grafindo, hlm. 12.
} 
perlindungan pada disabilitas antara lain: (i) Pasal 27 Ayat (2); (ii) Pasal $28 \mathrm{D}$ ayat (1); Pasal $28 \mathrm{I}$ ayat (2), Pasal $28 \mathrm{H}$ ayat (2), dan Pasal 34 ayat (3). ${ }^{26}$

Pada Pasal 27 ayat 2 UUD NRI merupakan dasar filosofis hak disabilitas, Makna dari pasal tersebut adalah bahwa negara mempunyai tanggung jawab terhadap hak konstitusional seluruh warga negaranya tidak terkecuali penyandang disabilitas sekalipun. ${ }^{27}$ Kemudian, Undang-Undang Dasar 1945 menjamin kesetaraan hak dan kesempatan setiap warga negara, termasuk warga negara difabel (khususnya lihat Pasal $28 \mathrm{H}$ ayat 2, dan Pasal 28 I ayat 2$).^{28}$

Dalam Pasal 28 I ayat (2) Undang-Undang Dasar Republik Indonesia Tahun 1945, menjelaskan bahwa "setiap orang berhak bebas dari perlakuan diskriminatif atas dasar apapun dan berhak mendapatkan perlindungan terhadap perlakuan diskriminatif tersebut" dan pada Pasal 34 ayat 3 UUD NRI juga dijelaskan bahwa "Negara mempunyai tanggung jawab atas penyediaan fasilitas kesehatan dan fasilitas pelayanan umum yang layak. Artinya, adanya amat untuk negara melindungi kaum yang rentan dan mereka wajib memfasilitasinya.

b. Undang-undang

Dalam Pengaturan selanjutnya yaitu pada tataran undangundang, dimana UU dinilai sebagai payung hukum yang secara sektoral mampu melindungi warga negaranya. Adapun aturan setingkat UU yang mengakomodir terkait hak disabilitas yaitu:

1) UU No 4 Tahun 1997 tentang Penyandang Cacat;

2) UU No 19 Tahun 2011 tentang Pengesahan (Ratifikasi) Konvensi Hak-Hak Penyandang disabilitas;

3) UU No 8 Tahun 2016 tentang Penyandang Disabilitas;

4) UU No 39 Tahun 1999 tentang Hak Asasi Manusia; ${ }^{29}$

5) UU No 13 Tahun 2003 tentang Ketenagakerjaan; ${ }^{30}$

6) UU No 23 Tahun 2002 tentang Perlindungan Anak; ${ }^{31}$

7) UU No 20 tahun 2003 tentang Sistem Pendidikan Nasional. ${ }^{32}$ Walaupun dari temuan di atas terdapat beberapa aturan setingkat UU yang mengatur hak para difabel. Namun, secara faktual masih kurang maksimal dan mengakomodir hak dari difabel. Sulitnya akses untuk difabel khususnya pada pencari keadilan mengakibatkan kemunduran bagi Indonesia dalam hak perlindungan HAM. Difabel sering menjadi korban dikarenakan secara kemampuan mereka dianggap sebagai pihak yang tidak cakap hukum dan implementatif

\footnotetext{
${ }^{26}$ Undang-Undang Dasar Negara Republik Indonesia Tahun 1945. Pasal 27 Ayat (2), Pasal 28 D ayat (1), Pasal 28 I Ayat (2), dan Pasal 34 Ayat (3).

${ }^{27}$ Riska Maulida, Dahlan, \& M. Nur Rasyid (2016). Perlindungan Hukum Bagi Pekerja Kontrak Waktu Tertentu Dalam Perjanjian Kerja, Kanun Jurnal Ilmu Hukum, Vol. 18, No. 4, hlm. 337.

28 Sunarman Sukamto, Best Practice Advokasi Kebijakan Daerah Perperspektif Difabel: Pengalaman PPRBM Solo, Solo: PPRBM Solo, hlm. 2.

${ }^{29}$ Pasal 3, 5 dan 41 UU No 39 Tahun 1999 tentang Hak Asasi Manusia

${ }^{30}$ Pasal 28 UU No 13 Tahun 2003 tentang Ketenagakerjaan.

${ }^{31}$ Pasal 8, 9, 11, 12, 13 UU No 23 Tahun 2002 tentang Perlindungan Anak.

32 Pasal 5 dan 23 UU No 20 tahun 2003 tentang Sistem Pendidikan Nasional.
} 
penggambaran perasaan mereka sulit untuk mengekspresikannya khusus pada penyandang intelektual.

c. Aturan lainnya

Aturan untuk menunjang UU No 8 Tahun 2016 berada pada tataran di bawah UU. Aturan ini dimaksudkan sebagai turunan dan teknis untuk mewujudkan pada hak-hak disabilitas terutama pada aksebilitasnya, adapun aturan lain dibawah UU mengenai disabilitas antara lain:

1) Peraturan Presiden Republik Indonesia Nomor 68 Tahun 2020 tentang Komisi Nasional Disabilitas; ${ }^{33}$ dan

2) Peraturan Menteri Pekerjaan Umum Nomor: 30/PRT/M/2006 tentang Pedoman Teknis Fasilitas dan Aksebilitas Pada Bangunan Gedung dan Lingkungan. ${ }^{34}$

2. Urgensi Revisi UU tentang Perlindungan Disabilitas dan korelasinya pada akses para penyandang mendapat perlindungan hukum pada kekerasan seksual.

Masih banyak amanat untuk membentuk peraturan pelaksana yang dari UU No.8/2016 yang belum terbentuk hingga saat ini sehingga berdasarkan ketentuan penutup di dalam Pasal 150 menyebutkan semua peraturan perundang undangan yang merupakan peraturan pelaksanaan dari UU No.4/1997 masih tetap berlaku sepanjang tidak bertentangan dengan ketentuan dalam UU No.8/2016 tersebut. ${ }^{35}$ kenyataan saat ini cukup memprihatinkan dikarenakan walaupun dahulu UU No 8/2016 dianggap sebagai pelita untuk menjamin hak-hak para difabel. Namun, UU tersebut juga memiliki beberapa kekurangan yang cukup menjadi urgensi untuk merevisinya agar nantinya bisa terciptanya progresivitas hukum di Indonesia. Adapun beberapa Urgensi revisi UU No 8 Tahun 2016 antara lain:

a. Ketidaktepatan pada Judul Undang-Undang pada perkembangan zaman

Urgensi pertama dari dilakukannya revisi UU a quo yaitu pada judul, dimana UU yang berjudul "Penyandang Disabilitas" dianggap kurang responsif dan kurang Uptudate pada perkembangan zaman. Dahulu alasan ini juga dipakai pada untuk merevisi UU No 4 Tahun 1997 Penyandang Cacat. Penyandang cacat merupakan istilah yang jamak digunakan tidak hanya oleh masyarakat, tapi juga oleh pemerintah selama belasan tahun ${ }^{36}$ dianggap kurang humanis dan condong diskriminatif.

Istilah disabilitas berasal dari kata dalam bahasa Inggris "disability". Beberapa penulis yang meneliti seputar difabilitas seringkali menggunakan istilah "disability". Kata tersebut berasal dari kata "dis" dan "ability" yang diterjemahkan sebagai ketidakmampuan. Secara lebih detail, disabilitas atau "disability" memiliki makna ketidakmampuan fisik dan/atau mental dan/atau intelektual sehingga

\footnotetext{
${ }^{33}$ Peraturan Presiden Republik Indonesia Nomor 68 Tahun 2020 tentang Komisi Nasional Disabilitas, (Lembar Negara Republik Indonesia Tahun 2020 Nomor 144).

${ }^{34}$ Peraturan Menteri Pekerjaan Umum Nomor: 30/PRT/M/2006 tentang Pedoman Teknis Fasilitas dan Aksebilitas Pada Bangunan Gedung dan Lingkungan.

${ }^{35}$ Frichy Ndaumanu (2020). Hak Penyandang Disabilitas: Antara Tanggung Jawab dan Pelaksanaan Oleh Pemerintah Daerah", Jurnal HAM, Vol. 11, No. 1, hlm.134.

${ }^{36}$ Setia Adi Purwanta, Penyandang Disabilitas, https://solider.or.id/sites/default/files/03.05.13PENYANDANG\%20DISABILITAS-dari\%20buku\%20vulnerable\%20group.pdf, (Diakses 16 Januari 2022).
} 
tidak mampu melakukan aktivitas sebagaimana orang "mampu" atau "normal". ${ }^{37}$ Istilah difabel ini menggantikan istilah "disabilitas" dan juga "cacat" yang mendahuluinya. Penggunaan kedua istilah terakhir sudah ditinggalkan karena tidak sesuai dengan perkembangan pemikiran terkait difabilitas. sebelum pembahasan istilah difabel, maka pembahasan istilah yang mendahuluinya yaitu "cacat" dan "disabilitas" akan dijelaskan terlebih dahulu. Kedua istilah tersebut sering didahului dengan kata "penyandang" ${ }^{38}$ Hal ini merujuk pada UN Convention on the Rights of Person with Disabilities (CRPD) yang diratifikasi melalui UU No. 19 tahun 2011 tentang pengesahan konvensi mengenai hak penyandang disabilitas. ${ }^{39}$ Penyandang disabilitas atau disebut juga "disabled person" atau "person with disabilities" merujuk kepada orang yang memiliki ketidakmampuan/keterbatasan fisik, mental, dan/atau intelektual. ${ }^{40}$

UU Penyandang Cacat tidak berlaku dan digantikan dengan UU No. 8 Tahun 2016 tentang Penyandang Disabilitas. Istilah "cacat" kemudian diganti dengan "disabilitas". Dalam UU tersebut, penyandang disabilitas adalah: ${ }^{41}$ Kesamaan pola ini menjadikan catatan untuk melakukan perubahan pada UU a quo. Adanya unsur diskriminasi pada satu UU jelas melanggar konstitusional. Dimana pada Pasal 28 I ayat (2) UUD NRI 1945 menyatakan " Setiap Orang bebas dari perlakuan Diskriminasi" itu artinya apapun dan bagaimanapun bentuk diskriminasi jelas tidak mendapatkan ruang di Indonesia. Istilah difabel juga termuat dalam catatan sejarah khususnya pada dokumen legal, berikut merupakan istilah difabel dalam dokumen legal.

Tabel 1. Istilah difabel dalam dokumen legal ${ }^{42}$

\footnotetext{
${ }^{37}$ Moh. Fuad Hasan (2012). Difabel: Mereka yang Terlupakan, Pledoi PUSHAM UII Edisi JuliAgustus, h. 10.

${ }^{38}$ Choky Risda Ramadhan, Fransiscus Manurung \& Adery Ardhan Saputro, Op.Cit. 9

${ }^{39}$ Ibid.

${ }^{40}$ Ibid.

${ }^{41}$ Pasal 1 ayat (1) Undang-Undang Republik Indonesia Nomor 8 Tahun 2016 tentang Penyandang Disabilitas

42 Arifi Maftuhin (2016). Mengikat Makna Diskriminasi Penyandang Cacat, Difabel, dan Penyandang Disabilitas, Journal Of Disability Studies, Vol. 3, No. 2, h. 144.
} 


\begin{tabular}{|c|c|}
\hline Istilah & Dokumen yang menggunakan \\
\hline (Ber)cacat & $\begin{array}{l}\text { Undang-undang No. } 33 \text { Tahun } 1947 \\
\text { tentang Ganti Rugi Buruh yang } \\
\text { Kecelakaan } \\
\text { Undang-undang No. 4 Tahun } 1979 \\
\text { tentang Kesejahteraan Anak }\end{array}$ \\
\hline $\begin{array}{l}\text { Orang-orang yang } \\
\text { dalam keadaan kekurangan } \\
\text { jasmani atau } \\
\text { rokhaninya }\end{array}$ & $\begin{array}{l}\text { Undang-undang Nomor } 12 \text { tahun } 1954 \\
\text { tentang Dasar-Dasar Pendidikan dan } \\
\text { Pengajaran di Sekolah Untuk Seluruh } \\
\text { Indonesia }\end{array}$ \\
\hline $\begin{array}{l}\text { Tuna } \\
\text { Orang yang terganggu atau } \\
\text { kehilangan kemampuan } \\
\text { untuk mempertahankan } \\
\text { hidupnya }\end{array}$ & $\begin{array}{l}\text { Undang-undang (Law) Nomor } 6 \text { Tahun } \\
1974 \text { tentang Ketentuan-ketentuan } \\
\text { Pokok Kesejahteraan Sosial }\end{array}$ \\
\hline Penderita Cacat & $\begin{array}{l}\text { Peraturan Pemerintah Nomor } 36 \text { Tahun } \\
1980 \text { tentang Usaha Kesejahteraan Sosial } \\
\text { Bagi Penderita Cacat } \\
\text { Undang-Undang Nomor } 14 \text { Tahun } 1992 \\
\text { tentang Lalu Lintas Angkutan Jalan }\end{array}$ \\
\hline Penyandang kelainan & $\begin{array}{l}\text { Peraturan Pemerintah Nomor } 72 \text { Tahun } \\
1991 \text { tentang Pendidikan Luar Biasa } \\
\text { Undang-undang Nomor } 20 \text { Tahun } 2003 \\
\text { tentang Sistem Pendidikan Nasional }\end{array}$ \\
\hline $\begin{array}{l}\text { Anak berkebutuhan khusus } \\
\text { (anak luar biasa) }\end{array}$ & $\begin{array}{l}\text { Surat Edaran Direktorat Jenderal } \\
\text { Pendidikan Dasar dan Menengah Tahun } \\
2003 \text { Perihal: Pendidikan Inklusi }\end{array}$ \\
\hline Penyandang cacat & \begin{tabular}{llrr} 
Pertama digunakan & \multicolumn{2}{c}{ Undang-Undang } \\
Nomor 15 & Tahun & 1992 & tentang \\
Penerbangan & & &
\end{tabular} \\
\hline
\end{tabular}

Penulis mengakui bahwa adanya perkembangan yang cepat pada ilmu pengetahuan nantinya akan berakibat pada kemungkinan munculnya definisi baru lagi yang dinilai lebih humas. Kekhawatiran pun timbul ketika ini dijadikan urgensi perubahan maka akan menciptakan ketidakpastian hukum. Namun, perlu dipahami bahwa alasan aktualisasi dan pembaharuan satu peraturan harus didasari pada fundamental dan dasar filsafat bangsa. Walaupun kedepan berkemungkinan akan muncul definisi baru terkait difabel atau lainnya yang lebih humanis dan akan ada revisi lagi itu sejatinya dibenarkan oleh UU. Timbulnya konotasi "Diskriminasi" dengan menggunakan kata "disabilitas" jelas mencederai konstitusi.Pelanggaran terjadi karena penyandang disabilitas tidak dianggap sebagai bagian dari warga negara, bahkan juga tidak dianggap manusia. ${ }^{43}$

Temuan lain terkait istilah yang belum relevan lainnya dikemukakan oleh Tarsidi. Tarsidi menolak istilah 'difabel'. Sebagai ganti 'penyandang cacat' ia pernah mengusulkan istilah 'penyandang ketunaan' pada tahun 2009 (Tarsidi \& Somad, 2009). ${ }^{44}$ Ini bisa menjadi bahan pertimbangan untuk dikaji lebih komprehensi lagi. Adanya potensi terlanggarnya

\footnotetext{
${ }^{43}$ Fajri Nursyamsi, dkk (2015). Kerangka Kelembagaan atas Hak Dasar Difabel yang Lumpuh di Indonesia, dalam Kamil Alfia Arifin ed. al, "Analekta Disabilitas: Sumbangsi untuk Pengayaan Rancangan Undang-undnag Disabilitas:, Jurnal Difabel, Vol. 2, No. 2, hlm. 352.

44 D. Tarsidi \& P. Somad (2009).Penyandang Ketunaan: Istilah Alternatif Terbaik untuk Menggantikan Istilah "Penyandang Cacat", Vol. 8 No.2, hlm. 128-132.
} 
ketentuan hak konstitusional warga negara maka berpeluang besar untuk UU a quo digugat di Mahkamah Konstitusi (MK). Judul yang direkomendasikan penulis untuk revisi UU tersebut yaitu dengan menambahkan frasa "Perlindungan" 45 dan pada frasa induk bisa menggunakan "difabel/penyandang ketunaan" dengan catatan semua istilah yang dipakai harus bebas dari konteks diskriminasi dan merendahkan difabel.

b. Kurang mengakomodir bentuk perlindungan pada kekerasan seksual pada difabel.

Urgensi selanjutnya untuk melakukan revisi UU No 8 Tahun 2016 dikarenakan kurang mengakomodir untuk bentuk perlindungan pada kekerasan seksual pada difabel. Walaupun dalam UU sudah terdapat beberapa frasa yang menjelaskan pada perlindungan kekerasan seksual, adapun pasal yang mengatur itu antara lain:

1) Pasal 5 ayat (2) $D$;

2) Pasal 5 Ayat (3) A;

3) Pasal $26 \mathrm{~B}$; dan

4) Pasal 128 ayat (2).

Dari keempat Pasal dalam UU sekiranya kurang mengakomodir dari keperluan pada perlindungan kekerasan seksual pada disabilitas. Kurang mengakomodirnya UU ini bisa dilihat dari CATAHU Komnas Perempuan pada 2021 yang sudah disinggung penulis pada latar belakang, dimana masih adanya korban kekerasan seksual pada disabilitas. Sejatinya angka yang dihimpun Komnas Perempuan masih jauh merepresentasikan kasus yang ada di Indonesia, dikarenakan dari indeks pendidikan, dan edukasi publik yang masih rendah mengakibatkan banyak kasus kekerasan seksual pada disabilitas yang belum terungkap.

UU No 8 Tahun 2016 sejatinya menjadi “Lex Specialis" pada perlindungan untuk difabel. Bukan hanya pada satu bidang saja tapi semua yang berkaitan pada ruang kajian difabel, karena difabel sejatinya memiliki kekhususan yang membedakan dengan manusia normal. Kemudian dalam UU a quo juga tidak secara rigid mengatur sanksi bagi para pelaku dan korban difabel terhadap kekerasan seksual juga menjadi catatan penting, dari penelusuran penulis sanksi yang terdapat dalam UU a quo hanya pada tataran sanksi administrasi pada penekanan penyediaan aksesibilitas sarana prasarana. Hal ini bisa dilihat dari penelusuran difabel yang berhadapan dengan hukum selalu dikenakan UU umum dan bukan khusus. berikut merupakan catatan kasus di pengadilan pada difabel.

Tabel 2 . Contoh Kasus di pengadilan pada Disabilitas ${ }^{46}$

\begin{tabular}{|c|c|c|}
\hline No & Putusan & \\
\hline \multicolumn{2}{|c|}{ Penerjemah Bagi Difabel Berhadapan dengan Hukum } \\
\hline
\end{tabular}

\footnotetext{
${ }^{45}$ Alasan ini berdasarkan pada pengkategorian Difabel sebagai pihak yang wajib dilindungi ( seperti pada (oppressed group), dimana uu serupa seperti pada perempuan ada UU PKDRT, kemudian anak UU Perlindungan anak. penggunaan frasa "perlindungan" dirasa cocok pada perkembangan zaman kelak.

${ }^{46}$ Rangkuman dari buku karangan, Choky Risda Ramadhan, Fransiscus Manurung \& Adery Ardhan Saputro (2016). Difabel Dalam Peradilan Pidana: Analisis Konsistensi Putusan, BP FHUI: Depok.
} 


\begin{tabular}{|c|c|}
\hline 1 & Perkara 52/PID.B/2013/PN.LBH \\
\hline 2 & Perkara 551/PID.B/2012/PN.Sbg \\
\hline 3 & Perkara 107/PID.B/2014/PN.Bko \\
\hline 4 & Perkara 171/PID.B/2014/PN.Pml \\
\hline \multicolumn{2}{|c|}{ Penggunaan Usia Korban Difabel Mental Intelektual } \\
\hline 5 & Perkara 20/PID.B/2014/PN.Kgn \\
\hline 6 & Perkara 158/PID.B/2014/PN. Unh \\
\hline 7 & Perkara 160/PID.B/2013/PN. PMS \\
\hline 8 & Perkara 221/PID.B/2014/PN. Kka \\
\hline 9 & Perkara 551/PID.B/2012/PN. Sbg \\
\hline \multicolumn{2}{|c|}{$\begin{array}{c}\text { Kekuatan Keterangan Ahli Sebagai Dasar Majelis Hakim Menentukar } \\
\text { Pertanggungjawaban Pidana terhadap Difabel }\end{array}$} \\
\hline 10 & Perkara 141/Pid.B/2010/PN.Kbm \\
\hline 11 & Perkara 874/Pid.B/2010/PN.SRG \\
\hline 12 & Perkara 190/Pid.B/2013/PN.MLG \\
\hline 13 & Perkara 833/Pid.B/2012/PN-TTD \\
\hline 14 & Perkara 16/Pid.B/2011/PN.BLK \\
\hline
\end{tabular}

Dari semua perkara di atas tidak melakukan rujukan pada UU No 4 Tahun 1997 tentang Penyandang Cacat dan UU No 19 Tahun 2011 tentang Pengesahan (Ratifikasi) Konvensi Hak-Hak Penyandang disabilitas. Kedua UU ini dipilih sebagai batu uji dikarenakan pada tahun itu UU 8 tahun 2016 belum secara penuh diketahui. Kemudian kita juga bisa berkaca bahwa pada faktanya di Indonesia saat ini khususnya pada ranah perdata terdapat gesekan pada UU 19 tahun 2011, adapun kontradiktif itu sebagai berikut: 
Tabel 3. Pemenuhan Hak CRPD dan KUHPerdata beserta Kontradiktifnya ${ }^{47}$

\begin{tabular}{|l|l|l|}
\hline \multicolumn{1}{|c|}{ CRPD } & \multicolumn{2}{|c|}{ KUHPerdata } \\
\hline \multicolumn{1}{|c|}{ Pemenuhan Hak } & \multicolumn{1}{|c|}{ Pemenuhan Ham } & $\begin{array}{l}\text { Kontradiktif } \\
\text { Pemenuhan } \\
\text { Hak }\end{array}$ \\
\hline Hak Asasi manusia (Pasal 1) & - & \multicolumn{1}{|c|}{} \\
\hline $\begin{array}{l}\text { Non Diskriminatif (Pasal 4- } \\
\text { 5 dan Pasal 23) }\end{array}$ & $\begin{array}{l}\text { Non diskriminatif (Pasal } \\
88 \text { dan Pasal 452) }\end{array}$ & - \\
\hline $\begin{array}{l}\text { Perempuan dan anak (Pasal } \\
\text { 6-7) }\end{array}$ & - & $\begin{array}{l}\text { Perempuan dan } \\
\text { Anak (Pasal }\end{array}$ \\
\hline $\begin{array}{l}\text { Non Stereotype (Pasal 8) } \\
\text { 283) }\end{array}$
\end{tabular}

${ }^{47}$ H. A. Dardiri Hasyim (2016). Identifikasi Pemenuhan Hak Bagi Difabel (Penyandang Cacat) dalam KUHperdata (Studi Analisis Pemenuhan Hak Bagi Difabel dalam KUHPerdata Perspektif Convention on the Rights of Persons With Disabilities dalam UU No 19 Tahun 2011)", Jurnal Serambi Hukum, Vol. 10. No. 2, hlm. 28-29. 


\begin{tabular}{|l|l|l|}
\hline $\begin{array}{l}\text { Pekerjaan dan lapangan } \\
\text { kerja (Pasal 27) }\end{array}$ & Pasal 441 dan Pasa 454 & - \\
\hline Jaminan sosial (Pasal 28) & Pasal 441 dan Pasal 454 & - \\
\hline Peran Serta (Pasal 30) & - & - \\
\hline Kerjasama (Pasal 32) & - & - \\
\hline TOTAL: 25 Pasal & TOTAL: 10 Pasal & $\begin{array}{c}\text { TOTAL: 5 } \\
\text { Pasal }\end{array}$ \\
\hline
\end{tabular}

Terdapat 5 (lima) pasal dalam KUHPerdata yang kontradiktif terhadap konsep pemenuhan hak sebagaimana tertuang dalam CRPD, yaitu kontradiktif pemenuhan Hak Asasi Manusia, Perempuan dan anak, serta Non stereotype. ${ }^{48}$ Dari sini muncul juga kecurigaan adanya gesekan antara UU lainnya yang diindikasi bergesekan dengan UU yang mengatur terkait difabel. Oleh karenanya tepat kiranya ketika dikatakan perlu adanya revisi dan spesifikasi aturan khususnya terkait perlindungan kekerasan seksual baik korban maupun pelaku difabel.

c. Komisi Nasional Disabilitas Independen yang kurang kurang tepat pembentukannya

Urgensi terakhir untuk melakukan revisi UU No 8 Tahun 2016 yaitu dikarenakan ketidak cocokan pada pembuatan Komisi Independen disabilitas, dimana UU ini mendelegasikan komisi independennya pada Peraturan Presiden Republik Indonesia No 68 Tahun 2020 tentang Komisi Disabilitas. Komisi ini sejatinya muncul tidak sesuai porsinya, dimana sifatnya yang independen justru mengakibatkan terhambatnya komisi dalam melakukan tugasnya. Tidak adanya komisi ini untuk dibuat secara independen justru berakibat fatal pada implementasinya. Dalam hal ini, Susan D. Bear (1988) mencatat, bahwa ketidakpercayaan publik (public distrust) terhadap lembaga negara yang ada, telah mendorong lahirnya lembaga independen untuk melaksanakan tugas dan diidealkan memberikan kinerja baru yang lebih terpercaya. Faktor itu menjadi salah satu pemicu lahirnya lembaga negara federal. ${ }^{49}$ Beberapa basis argumentasi yang dapat ditemukan sebagai pencetusan pembentukan lembaga-lembaga tersebut adalah: (1) refori dengan Pendekatan NeoLiberal; (2) kewajiban Transisi untuk menunjang Hal Tertentu; (3) kebutuhan Percepatan Demokrasi; (4) bagian dari Pencitraan kekuasaan; (4) mengurangi Persengketaan Langsung antara Negara dengan Warga; (5)

\footnotetext{
${ }^{48}$ H. A. Dardiri Hasyim (2016). Identifikasi Pemenuhan Hak Bagi Difabel (Penyandang Cacat) dalam KUHperdata (Studi Analisis Pemenuhan Hak Bagi Difabel dalam KUHPerdata Perspektif Convention on the Rights of Persons With Disabilities dalam UU No 19 Tahun 2011)", Jurnal Serambi Hukum, Vol. 10. No. 2, hlm. 29.

${ }^{49}$ Susan D, Bear (1988). The Public Tryst Doctrine- A Tool to Make Federal Administrative Agencies Increase Protection of Public Law and Its Resources, Boston College Environmental Affairs Law Review, Vol. 15, hlm.382.
} 
kekecewaan Terhadap Kelembagaan Lama; (6) menunjukan Kinerja untuk Hal Tertentu;dan (7) ketergesa-gesaan dalam legislasi. ${ }^{50}$

Dari alasan hadirnya lembaga Independen jelas bahwa Komisi Nasional Disabilitas tidak memiliki kriteria lahirnya komisi independen. Ketidaktepatan ini jelas menimbulkan kerugian, baik pada difabel maupun pada negara. Dari fakta yang ada sering lembaga independen tidak selaras dengan yang diharapkan. Berdasarkan roadmap Kementerian Pendayagunaan Aparatur Negara dan Reformasi Birokrasi, sejak 2014 hingga 2020, pemerintahan Jokowi telah membubarkan 27 lembaga non struktural. Adapun perincian LNS dibubarkan adalah 2014 sebanyak 10 lembaga, 2015 sebanyak 2 lembaga, 2016 sebanyak 9 lembaga, 2017 sebanyak 2 lembaga, dan 20204 lembaga. Adapun total LNS yang semula 120 LNS, kini hanya tersisa 93 LNS. ${ }^{51}$ Bahkan menurut menteri Pendayagunaan Aparatur Negara dan Reformasi Birokrasi Tjahjo Kumolo dalam wawancaranya dengan CNBC Indonesia, Rabu 16 September 2021 mengatakan, tak menutup kemungkinan akan ada pembubaran lembaga tahap selanjutnya. ${ }^{52}$

Ketika point-point bermasalah yang telah penulis jabarkan, ketika hal itu dibenahi diharapkan dapat menciptakan efektifitas dan fokus penanganan yang tepat. Hal ini jelas akan berimplikasi pada semakin terciptanya perlindungan hukum dan kepastian hukum pada kekerasan seksual baik pada korban maupun pelaku difabel.

\section{KESIMPULAN DAN SARAN}

\section{A. Kesimpulan}

Pada kesimpulan yang bisa dipetik dari karya tulis ilmiah yaitu:

1. Hukum positif di Indonesia saat ini belum secara komprehensif baik secara substansial normatif, doktrinal, teologis, dan kontekstual yang bener-benar mengakomodir keperluan Difabel. Kemudian, masih seringnya aparat penegak hukum untuk menggunakan aturan umum saat menangani pelaku atau korban dari difabel. Adapun sejauh ini terdapat UU yang membahas terkait difabel antara lain: (i) UU No 19 Tahun 2011 tentang Pengesahan Ratifikasi Konvensi Hak-hak Penyandang Disabilitas; (ii) UU No 8 Tahun 2016 tentang Penyandang Disabilitas.

2. Urgensi dari ide untuk merevisi UU No 8 Tahun 2016 tentang Disabilitas yaitu karena. Pertama, masih kurangnya akomodir hak-hak penting khusus penyandang disabilitas yang terkandung di dalamnya. Kedua, terkesan mendiskriminasi pada Difabel mengingat pada kontek judul UU menggunakan kata "Disabilitas" yang diartikan sebagai "Penyandang cacat atau ketidakmampuan fisik", pada perkembangannya nama disabilitas sejatinya sudah tergeser dengan frasa yang lebih humanis dan adem yaitu "Difabel" yang artinya "kemampuan berbeda". Ketiga, pada konteks pemberlakuan khusus pada penanganan difabel berhadapan dengan hukum. Konteks ini menitik beratkan pada pemindah tanganan pengaturan hukum ketika difabel berhadapan dengan hukum, seperti menggunakan beberapa

\footnotetext{
50 Zainal Arifin Mochtar (2019). Lembaga Negara Independen: Dinamika Perkembangan dan Urgensi Penataannya Kembali Pasca- Amandemen Konstitusi. Cetak ke-3, Depok: Rajawali Pers, hlm. 114.

51 Chandra Gian Asmara, "Sudah Berapa Lembaga Negara Sih yang Dibubarkan Jokowi?", https://www.cnbcindonesia.com/news/20200916113622-4-187195/sudah-berapa-lembaga-negarasih-yang-dibubarkan-jokowi, diiakses pada 2 Februari 2021.

${ }^{52} \mathrm{Ibid}$
} 
dakwaan, hal ini tergolong salah dimana pertama difabel secara age kalender atau kemampuan kognitif tergolong subjek tidak cakap hukum, kedua secara kesadaran ia tergolong pada usia anak khusus pada Difabel intelektual dan walaupun usianya tua. Keempat, Komisi Nasional Disabilitas Independen yang kurang kurang tepat pembentukannya, dimana independensi ini mengakibatkan komisi ini terhambat dalam melaksanakan tugasnya, kemudian dalam urgensi independensi tidak memiliki kaitan pada penyimpangan kekuasaan, maka darinya perlu merevisi ketentuan Komisi Nasional Disabilitas independen ini.

3. Dengan melakukan Revisi UU tentang perlindungan Disabilitas kelak bisa menjadi aksesibilitas di Indonesia. dikarenakan semakin komprehensifnya pada penjaminan hak-hak khusus yang diperuntukan hanya pada difabel.

\section{B. Saran}

Melengkapi pelayaran dari tulisan karya ilmiah di atas, maka tepat kiranya penulis memberikan rekomendasi atau saran guna menunjang gagasan untuk merevisi UU No 8 Tahun 2016, adapun saran yang direkomendasikan penulis sekiranya merupakan saran yang aplikatif dan sangat mungkin diimplementasikan, berikut merupakan saran dari penulis:

1. Melakukan revisi UU No 8 Tahun 2016 tentang Penyandang Disabilitas, dimana pada muatannya DPR perlu melakukan tinjauan ulang mengenai perlindungan difabel untuk mendapat akses perlindungan pada kekerasan seksual. Revisi pada UU itu meliputi pada perubahan pada judul UU, kemudian melakukan penambahan pasal membahas terkait kekerasan seksual pada difabel, kemudian melakukan penambahan sanksi dalam UU khususnya yang berkaitan dengan pidana. dan terakhir melakukan revisi pada komisi independen nasional disabilitas untuk menurunkan kedudukannya menjadi tidak independen dan dibawah naungan kementrian saja, lembaga itu kelas akan berbentuk Lembaga Eksekutif Struktural (LES) dan pegawainya masuk pada ASN.

2. Melakukan rekomendasi pada Lembaga Swasta Masyarakat (LSM) untuk melakukan Judicial review ke Mahkamah Konstitusi pada UU No 8 Tahun 2016 tentang penyandang disabilitas untuk membatalkan UU a quo. Kemudian meminta pada mahkamah untuk memberikan rekomendasi pada DPR untuk merevisi UU ini, kasus yang menjadi rekomendasi seperti pada penggugatan DPD pada UU No 12 Tahun 2011 tentang Pembentukan Peraturan Perundang-undangan yang diubah menjadi UU No 15 Tahun 2019.

\section{DAFTAR PUSTAKA \\ BUKU}

Soekanto, S., \& Mamudji, S. (2019). Penelitian Hukum Normatif (Suatu Tinjauan Singkat). Jakarta: Raja Grafindo.

Ishaq, H. (2017). Metode Penelitian Hukum dan Penulisan Skripsi, Tesis, serta Disertasi. Alfabeta, 26.

Marzuki, P. M. (2017). Penelitian Hukum Edisi Revisi. Jakarta: Kencana Prenada Media Group. . (2019). Penelitian Hukum. Jakarta: Pranada Media Group.

Mochtar, Z. A. (2019). Lembaga Negara Independen: Dinamika Perkembangan dan Urgensi Penataannya Kembali Pasca- Amandemen Konstitusi. Depok: 144. 
Soekanto, S. (2001). Penelitian Hukum Normatif Suatu Tinjauan Singkat. Jakarta: Raja Grafindo.

Sugiono. (2012). Memahami Penelitian Kualitatif. Alfabeta, 141.

Sukamto Sunarman (2013). Best Practice Advokasi Kebijakan Daerah JURNAL Perperspektif Difabel: Pengalaman PPRBM Solo, Solo: PPRBM Solo, 2.

Anam, M. M., \& Arifin, R. (2019). Aksesibilitas Kaum Difabel Dalam Perlindungan Hukumnya Dalam Perspektif Hak Asasi Manusia. Pena Jurnal, 52.

Budiyono, Muhtadi, \& Firmansyah, A. A. (2015). Dekontruksi Urusan Pemerintah Konkuren Dalam Undang-Undang Pemerintahan Daerah. Kanun Jurnal Ilmu Hukum, 416.

D, S., \& Bear. (1988). The Public Tryst Doctrine- A Tool to Make Federal Administrative Agencies Increase Protection of Public Law and Its Resources. Boston College Environmental Affairs Law Review, 382.

Hasan, M. F. (2012). Difabel: Mereka yang Terlupakan. Pledoi PUSHAM UII , 10.

Hasyim, H. D. (2016). Identifikasi Pemenuhan Hak Bagi Difabel (Penyandang Cacat) dalam KUHperdata (Studi Analisis Pemenuhan Hak Bagi Difabel dalam KUHPerdata Perspektif Convention on the Rights of Persons With Disabilities dalam UU No 19 Tahun 2011). Serambi Hukum, 28-29.

Hendrik, M. M. (2006). Jenis, Metode, dan Pendekatan dalam Penelitian Hukum. Jurnal Law Review, 1994.

Idris, M. (2020). Upaya Perlindungan Hukum Terhadap Kaum Penyandang Disabilitas Dari Kejahatan Pelecehan Seksual (Studi Kasus Unit Pelaksana Teknis Daerah Perlindungan Perempuan Dan Anak (UPTD PPA) Kota Jambi). UIN Sutha Jambi, 36-37.

Komnas, P. (2021). Catatan Tahunan Kekerasan Terhadap Perempuan. Jakarta: KOMNAS PEREMPUAN.

Maftuhin, A. (2016). Mengikat Makna Diskriminasi Penyandang Cacat, Difabel, dan Penyandang Disabilitas. Journal Of Disability Studies, 144.

Maulida, R., Dahlan, \& Rasyid, M. N. (2016). Perlindungan Hukum Bagi Pekerja Kontrak Waktu Tertentu Dalam Perjanjian Kerja. Kanun Jurnal Ilmu Hukum, 337.

Muladi, H. (2005). Hak Asasi Manusia Hakekat, Konsep \& Implikasi Dalam Perspektif Hukum dan Masyarakat. Refika Aditama, 225.

Ndaumanu, F. (2020). Hak Penyandang Disabilitas: Antara Tanggung Jawab dan Pelaksanaan Oleh Pemerintah Daerah. Jurnal HAM, 132-133.

Nursyamsi, F., \& dkk. (2015). Kerangka Kelembagaan atas Hak Dasar Difabel yang Lumpuh di Indonesia, dalam Kamil Alfia Arifin ed. al, "Analekta Disabilitas: Sumbangsi untuk Pengayaan Rancangan Undang-undnag Disabilitas. Jurnal Difabel, 352.

Ramadhan, C. R., Manurung, F., \& Saputro, A. A. (2016). Difabel Dalam Peradilan Pidana: Analisis Konsistensi Putusan. Depok: BP FH UI.

Setyaningsih, R. (2016). Pengembangan Kemandirian Bagi Kaum Difabel. Sosiologi Dilema, 43.

Tarsidi , D., \& Somad, P. (2009). Penyandang Ketunaan: Istilah Alternatif Terbaik untuk Menggantikan Istilah "Penyandang Cacat". JASSI_Anakku, 128-132.

Tohari, S. (2014). Pandangan Disabilitas dan Aksesibilitas Fasilitas Publik bagi Penyandang Disabilitas di Kota Malang. Indonesia Journal Of Disability Studies, 29. 
Umam , M. M., \& Arifin, R. (2019). Aksesibilitas Kaum Difabel Dalam Perlindungan Hukumnya Dalam Perspektif Hak Asasai Manusia. Pena Jurnal, 52.

Usman , H., \& Akbar, P. S. (1996). Metodologi Penelitian Sosial. Bumi Aksara, 42. Sukamto Sunarman (2013). Best Practice Advokasi Kebijakan Daerah Perperspektif Difabel: Pengalaman PPRBM Solo, Solo: PPRBM Solo, 2.

\section{PERATURAN PERUNDANG-UNDANGAN}

Indonesia. Undang-Undang Dasar Negara Republik Indonesia Tahun 1945. .Undang-Undang Republik Indonesia Nomor 8 Tahun 2016 tentang Penyandang Disabilitas .Undang-Undang No 39 Tahun 1999 tentang Hak Asasi Manusia .Undang-Undang No 13 Tahun 2003 tentang Ketenagakerjaan .Undang-Undang No 23 Tahun 2002 tentang Perlindungan Anak .Undang-Undang No 20 tahun 2003 tentang Sistem Pendidikan Nasional .Peraturan Presiden Republik Indonesia Nomor 68 Tahun 2020 tentang Komisi Nasional Disabilitas .Peraturan Menteri Pekerjaan Umum Nomor: 30/PRT/M/2006 tetang Pedoman Teknis Fasilitas dan Aksebilitas Pada Bangunan Gedung dan Lingkungan.

.Peraturan Menteri Pekerjaan Umum Nomor: 30/PRT/M/2006 tetang Pedoman Teknis Fasilitas dan Aksebilitas Pada Bangunan Gedung dan Lingkungan.

\section{Berita/Artikel Online}

Barnes, Colin. (n.d.). The Social Model of Disability: Valuable or Irrelevant? From http://www.mcgill.ca/files/osd/TheSocialModelofDisability.pdf, diakses pada 1 Februari 2022.

$\begin{array}{lllll}\text { Purwanta, Setia Adi. (n.d.). Penyandang Disabilitas. } & \text { From }\end{array}$ https://solider.or.id/sites/default/files/03.05.13-

PENYANDANG\%20DISABILITAS-dari\%20 buku\%20vulnerable\%20group.pdf, diakses pada 16 Januari 2022.

Asmara, Chandra Gian . "Sudah Berapa Lembaga Negara Sih yang Dibubarkan Jokowi? From https://www.cnbcindonesia.com/news/20200916113622-4187195/sudah-berapa-lembaga-negara-sih-yang-dibubarkan-jokowi, diakses pada 2 Februari 2022. 